\title{
KESALAHAN PEMAKAIAN BAHASA INDONESIA MEDIA LUAR RUANG DI KOTA TANGERANG SELATAN
}

\author{
Bram Denafri ${ }^{1}$, Washadi ${ }^{2}$ \\ bram@unpam.ac.id ${ }^{1}$, hdsastra47@gmail.com ${ }^{2}$ \\ Universitas Pamulang
}

\begin{abstract}
This research is urgent to do considering the use of Indonesian outdoor media which is increasingly complex and uncontrolled. This issue has led to the development of a wide variety of written media in outdoor media whose rules deviate significantly from the Indonesian Spelling General Guidelines. The inconsistency between the rules and the use of various languages will lead to the skepticism of Indonesian people to use Indonesian properly and correctly. Also, the development of the Indonesian language that is not based on good linguistic knowledge will lead to the erosion of the Indonesian language and irregular language growth. Therefore, this research is important to do to see patterns of Indonesian language mistakes in outdoor media. With the hope that the Indonesian Spelling Guidelines are applied in a basic and solid manner in the use of Indonesian outdoor media. This type of research is a descriptive study with a qualitative approach. This research tries to understand and explain the phenomena of misuse of the Indonesian language in outdoor media in South Tangerang City. This research produces descriptive data in the form of sentences in outdoor media in South Tangerang City. Sources of data in this study were obtained from written sources. Sources of written data were obtained from billboards, billboards, banners, billboards, and neon boxes.
\end{abstract}

Keywords: Indonesian, language error, outdoor media

\section{A. PEndahuluan}

Tujuan penelitian ini sejalan dengan salah satu misi Badan Pengembangan dan Pembinaan Bahasa, yaitu meningkatkan mutu kebahasaan dan pemakaiannya. Peningkatan mutu kebahasaan dapat dilakukan pelibatan publik dan pemanfaatan media baru. Salah satu media publik yang harus ditingkatkan mutu kebahasaan dan pemakaiannya adalah media luar ruang. Media luar ruang merupakan salah satu jenis komunikasi massa yang ditujukan untuk masyarakat umum. Media luar ruang biasanya dimanfaatkan oleh pemerintah, lembaga, pebisnis, organisasi dan perorangan. Media ini dimanfaatkan dengan tujuan untuk menyampaikan pesan, informasi dan bersifat mengajak para pembacanya.

Penyampaian pesan dan informasi media luar ruang disampaikan menggunakan bahasa Indonesia. Penggunaan bahasa Indonesia media luar ruang saat ini semakin 
OUmanitatis

Journal on Language and Literature Vol. 6 No. 2 June 2020

kompleks dan tidak terkendali. Persoalan ini mengakibatkan degradasi mutu pemakaian bahasa media luar ruang. Hal ini dibuktikan dengan munculnya perkembangan ragam bahasa tulis media luar ruang yang kaidah-kaidahnya banyak menyimpang dari Pedoman Umum Ejaan Bahasa Indonesia.

Degradasi mutu pemakaian bahasa Indonesia media luar ruang ini disebabkan oleh berbagai faktor. Pertama, disebabkan karena rendahnya pengetahuan pemilik atau pembuat varian komunikasi media luar ruang mengenai Pedoman Umum Ejaan Bahasa Indonesia. Kedua, dipengaruhi oleh pengaruh dominasi bahasa asing (bahasa Inggris) dan bahasa daerah sehingga memengaruhi masyarakat Indonesia berbahasa Indonesia secara baik dan benar berpedoman pada Pedoman Umum Ejaan Bahasa Indonesia.

Persoalan ini jika dibiarkan begitu saja tanpa ada pembinaan akan menimbulkan kesangsian masyarakat Indonesia untuk memakai bahasa Indonesia sesuai dengan Pedoman Umum Ejaan Bahasa Indonesia. Selain itu, pengembangan bahasa Indonesia yang tidak didasarkan pada pengetahuan ilmu bahasa (linguistik) yang baik akan menimbulkan pengikisan bahasa Indonesia dan pertumbuhan bahasa yang tidak teratur (Badan Pengembangan dan Pembinaan Bahasa, 2011). Oleh karena itu, penelitian ini penting dilakukan untuk meningkatkan kembali mutu kebahasaan dan pemakaiaan bahasa Indonesia media luar ruang. Selain itu, penelitian ini mendesak dilakukan untuk melihat pola kesalahan kaidah pemakaian bahasa Indonesia media luar ruang. Dengan harapan agar Pedoman Ejaan Bahasa Indonesia bisa diterapkan secara mantap pada media luar ruang.

Hasil penelitian ini dapat dijadikan sebagai dasar untuk melihat sejauh mana penerapan dan sosialisasi Undang-Undang Republik Indonesia nomor 24 tahun 2009, pasal 36 ayat 3 dan Pedoman Umum Ejaan Bahasa Indonesia pada media luar ruang. Selain itu, hasil penelitian ini diharapakan dapat dijadikan sebagai dasar bagi Badan dan Pengembangan dan Pembinaan Bahasa untuk membuat sebuah pedoman atau regulasi pemakaian bahasa Indonesia media luar ruang.

Nida dan Taber (1982: 12) menyatakan bahwa, "Translatingconsist of reproducing in the receptor language natural equivalent of the sourcelanguage 
message, first in terms of message and secondly in term of style". Dari pernyataan Nida dan Taber, terdapat dua hal di dalam proses penerjemahan. Yang pertama adalah menghasilkan pesan yang sepadan dengan bahasa sumber, dan yang kedua adalah menghasilkan kesepadanan yang alamiah dalam hal gaya. Namun, penerjemahan dalam hal gaya adalah sesuatu yang rumit. Nababan (2008:59) menyatakan bahwa kompleksitas stilistik merupakan salah satu faktor penyebab sulitnya penerjemahan dilakukan. Dalam proses penerjemahan, penerjemah sering kali menjumpai persoalan. Teknik penerjemahan diperlukan untuk memecahkan berbagai persoalan tersebut. Teknik penerjemahan adalah cara yang digunakan untuk mengalihkan pesan dari BSu ke BSa, diterapkan pada tataran kata, frasa, klausa maupun kalimat. Menurut Molina dan Albir (2002), teknik penerjemahan memiliki lima karakteristik yaitu 1) memengaruhi hasil terjemahan, 2) diklasifikasikan dengan perbandingan pada teks Bsu, 3) berada pada tataran mikro, 4) tidak saling berkaitan tetapi berdasarkan kontekstertentu, dan 5) bersifat fungsional. Penggunaan teknikteknik penerjemahan akan membantu penerjemah dalam menentukan bentuk dan struktur kata, frasa, klausa, serta kalimat terjemahannya. Selain, itu penerjemah juga akan terbantu dalam menentukan padanan yang paling tepat didalam bahasa sasaran. Dengan demikian, kesepadanan terjemahan dapat diterapkandalam berbagai satuan lingual. Selain itu, penggunaan teknik penerjemahan tidak hanya akan menghasilkan terjemahan yang akurat tetapi juga berterima dan mudah dibaca oleh pembaca teks sasaran.

Berdasarkan pada latar belakang diatas maka dapat disimpulkan bahwa perlunya penerjemahan yang sesuai atau sepadan selama kata, frasa, dan kalimat pada pada bahasa sumber masih bisa diterjemahkan dan adanya isitlah yang sesuai pada bahasa Indonesia. Dengan hasil penerjemahan yang berkualitas tidak hanya akurat tetapi juga dapat dipahami dan alamiah akan memudahkan pembaca bahasa sasaran dalam memahami teks yang dieterjemahkan. Adapun tujuan penelitian ini adalah untuk menjabarkan penggunaan ideologi penerjemahan ole $h$ mahasiswa dalam teks terjemahan mahasiswa serta mendeskripsikan penggunaan 


\section{Oumanitatis}

Journal on Language and Literature Vol. 6 No. 2 June 2020

teknik penerjemahan oleh mahasiswa dalam teks terjemahan mahasiswa STIBA Bumigora.

\section{B. TINJAUAN PUSTAKA}

Pada subbab tinjauan pustaka ini diuraikan sejumlah kajian terdahulu yang memiliki relevansi dengan penelitian ini. Kajian itu baik berupa buku maupun hasilhasil penelitian yang berkaitan dengan kesalahan penggunaan bahasa Indonesia pada media luar ruang. Sejauh penelusuran studi pustaka yang telah dilakukan, ditemukan beberapa penelitian sebelumnya terkait kesalahan penggunaan bahasa Indonesia pada media luar ruang.

Hasanudin (2017) mengkaji kesalahan berbahasa Indonesia pada penulisan media luar ruang di Kabupaten Bojonegoro. Beliau mengkaji 3 pokok permasalahan dalam penelitian ini. Pertama, menjelaskan bentuk kesalahan berbahasa Indonesia pada penulisan media luar ruang di Kabupaten Bojonegoro. Kedua, mejelaskan kesalahan penggunaan unsur asing. Ketiga, mengetahui kesesuaian hasil penelitian dengan materi ajar bahasa Indonesia pada Sekolah Menengah Pertama. Berdasarkan hasil penelitianya, dia menemukan 3 fakta. Pertama, unsur kebahasaan yang sering terjadi kesalahan berbahasa dalam media luar ruang yaitu kesalahan pada aspek pemakaian tanda baca, khususnya tanda titik (.), penulisan kata depan di, penggunaan kata pukul dan jam, dan singkatan. Kedua, jenis kesalahan pemakaian istilah asing didominasi dengan penggunaan bahasa Inggris dan bahasa Jawa. Kedua bahasa tersebut digunakan bersamaan pada setiap kata atau frasa bahasa Indonesia. Ketiga, hasil penelitian ini sesuai jika digunakan sebagai materi ajar matapelajaran bahasa Indonesia di jenjang Sekolah Menengah Pertama, khususnya pada materi tentang ejaan dan istilah asing (unsur serapan).

Penelitian ini belum secara menyeluruh atau tuntas membahas kesalahan berbahasa Indonesia di Kabupaten Bojonegoro. Hal ini dapat dilihat dari jumlah sampel yang digunakan dalam penelitian ini, yaitu 10 media luar ruang. Sepuluh sampel ini dirasa belum cukup dalam penelitian ini, karena judul penelitiannya yang begitu luas mencakup seluruh Kabupaten Bojonegoro. Afifah dan Nikmah (2017) 
meneliti tentang Analisis Kesalahan Berbahasa Pada Penulisan Media Luar Ruang Di Wilayah Kota Medan. Hasil penelitiannya menemukan bahwa penulisan media luar ruang di wilayah Kota Medan masih ditemukan banyak kesalahan, baik dari segi penulisan kesalahan ejaan, tanda baca, dan pilihan kata (diksi). Pendekatan yang digunakan dalam penelitian ini adalah pendekatan teoritis dan metodologis. Pendekatan teoritis dalam penelitian ini menggunakan analisis pendekatan kesalahan bahasa Indonesia, sedangkan pendekatan metodologis yang digunakan adalah pendekatan deskriptif kualitatif. Pengumpulan data dilakukan dengan menggunakan metode observasi langsung (observasi), catatan teknis, dan dokumentasi. Analisis data menggunakan teknik pemilahan dan ganti teknik. Presentasi menggunakan metode informal analisis data. Hasil yang diperoleh masih banyak kesalahan menulis di media luar ruang di Kota Medan yang tidak sesuai dengan aturan Indonesia. Bentuk-bentuk kesalahan penulisan di media luar ruang di Kota Medan meliputi kesalahan penulisan tanda baca, kesalahan penulisan singkatan, kesalahan penggunaan huruf kapital, kesalahan pemilihan kata, dan kesalahan penulisan ejaan.

Susanti dan Dewi Agustini (2016) dalam penelitiannya yang berjudul Analisis Kesalahan Berbahasa pada Penulisan Iklan Luar Ruang di Kota Surakarta. Temuan penelitian ini dapat disimpulkan bahwa kesalahan berbahasa Indonesia pada penulisan media iklan luar ruang di Kota Surakarta masih banyak dijumpai yang belum/tidak sesuai dengan kaidah bahasa Indonesia yang baik dan benar. Bentukbentuk kesalahan penulisan pada media iklan luar ruang di Kota Surakarta meliputi kesalahan penulisan tanda baca, kesalahan penulisan singkatan,kesalahan penggunaan huruf kapital, kesalahan pemilihan diksi, dan kesalahan penulisan ejaan.

Utari (2018) dalam penelitiannya yang berjudul Analisis Kesalahan Berbahasa Pada Penulisan Media Luar Ruang Di Kota Jakarta Timur. Permasalahan utama yang diatasi dalam penelitian ini adalah mengenai banyaknya terpaan gelombang globalisasi pada bahasa Indonesia. Hal ini terlihat dengan semakin tergesernya bahasa Indonesia oleh bahasa asing dengan banyaknya penggunaan bahasa asing di ruangruang publik. Selain itu, mutu penggunaan bahasa Indonesia di berbagai ranahpun 
sangat rendah. Hal ini terlihat dari banyaknya kesalahan-kesalah tulis baik berupa diksi, ejaan, maupun kata yang digunakan.

Penelitian ini bertujuan untuk menganalisis dan menguraikan kesalahan berbahasa pada penulisan media luar ruang di wilayah kota Jakarta Timur. Metode yang digunakan adalah metode simak, rekam, dan catat dengan menggunakan pendekatan deskriptif. Pengumpulan data dengan menggunakan studi pustaka, observasi, dan dokumentasi. Teknik analisis data dengan memilah, mendeskripsikan, dan menguraikan hasil temuan lapangan serta memberi solusi atas permasalahan dalam pemakaian bahasa Indonesia. Desain penelitian yang dilakukan yaitu tahap awal berupa pencarian studi pustaka dan pengamatan media luar di wilayah Jakarta Timur. Selanjutnya melakukan pengumpulan data dengan merekam data yang diperoleh. Setelah itu data di analisis dan dilakukan evaluasi.

Kesimpulan hasil penelitian ini adalah 18 kesalahan berbahasa pada penulisan media luar ruang publik di wilayah Jakarta Timur. Kesalahan-kesalahan tersebut terdiri dari 11 kesalahan berbahasa Indonesia dan 7 kesalahan penggunaan unsur asing. Unsur kesalahan berbahasa dalam media luar ruang di antaranya yaitu kesalahan pada aspek penulisan singkatan dan akronim, kesalahan penggunaan huruf kapital, kesalahan penulisan tanda baca, pemilihan kata yang tepat, dan kesalahan penulisan nama diri dan gelar. Adapun kesalahan penggunaan unsur asing yaitu kesalahan penulisan unsur serapan asing dari bahasa Inggris, bahasa Arab, dan bahasa Belanda.

Damayanti (2019) dalam penelitiannya yang berjudul Kesalahan Penggunaan Bahasa Pada Iklan Komersial Media Luar Ruang Di Kabupaten Kediri. Penelitian ini bertujuan untuk menganalisis kesalahan berbahasa dari segi ejaan dan struktur frasa pada penggunaan bahasa iklan media luar ruang di Kabupaten Kediri. Penelitian ini menggunakan metode kualitatif deskriptif. Wujud data dalam penelitian ini berupa kata-kata, kalimat, dan wacana yang berupa papan nama, baliho, dan spanduk yang terdapat di wilayah Kabupaten Kediri. Teknik pengambilan sampel yang digunakan pada penelitian ini adalah teknik purposive sampling. Dalam hal ini peneliti memilih iklan komersial media luar ruang di tiga wilayah Kabupaten Kediri, yaitu Kecamatan 
Ngasem, Gurah, dan Pare. Teknik pengumpulan data yang digunakan dalam penelitian ini adalah teknik dokumentasi, catat dan simak. Sementara itu, analisis data yang dilakukan dalam penelitian ini terdiri dari tiga komponen, yaitu pengumpulan data, pengolahan data, dan penarikan kesimpulan.

Hasil penelitian ini menunjukkan bahwa masih ada kesalahan bahasa pada penggunaan iklan komersial media luar ruang di Kabupaten Kediri. Kesalahan tersebut berupa kesalahan ejaan dan ketidaktepatan dalam struktur frasa. Kesalahan ejaan terdiri dari kesalahan pada tanda baca, unsur serapan (kata baku/tidak baku), dan penulisan kata. Untuk penggunaan struktur frasa dalam penelitian ini dijumpai adanya papan nama yang menggunakan kosakata bahasa Inggris dengan struktur frasa bahasa Inggris, penggunaan kosakata bahasa Indonesia dan bahasa Inggris, tetapi menggunakan struktur frasa bahasa Inggris, dan yang terakhir penggunaan kosakata bahasa Inggris dan Indonesia, tetapi menggunakan frasa bahasa Indonesia.

Berdasarkan tinjauan kepustakaan di atas, maka penelitian ini berbeda dengan penelitian sebelumnya. Dalam penelitian ini yang dikaji adalah degradasi mutu pemakaian bahasa Indonesia media luar ruang di Kota Tangerang Selatan. Penelitian ini saling berhubungan dengan penelitian sebelumnya karena penelitian ini muncul setelah adanya penelitian-penelitian terdahulu beserta temuannya. Landasan teori yang digunakan dalam penelitian ini adalah teori kesalahan berbahasa yang dikemukakan oleh Ghufron (2015). Kesalahan berbahasa dibagi menjadi 4 kategori, yaitu kesalahan fonologi, kesalahan morfologi, kesalahan sintaksis, dan kesalahan leksikon. Kesalahan fonologi biasanya ditemukan dalam bentuk kesalahan pelafalan dan penulisan. Kesalahan ini terdiri dari kesalahan penulisan atau pemakaian (1) kata dasar, (2) huruf kapital, (3) prefiks yang seharusnya preposisi, (4) preposisi yang seharusnya prefiks, (5) klitika, (6) singkatan, dan (7) tanda baca. Kesalahan morfologi adalah kesalahan yang terjadi pada tataran morfologi (proses pembentukan kata). Kesalahan ini terdiri dari kesalahan penggunaan afiks, kesalahan reduplikasi dan kesalahan komposisi (kata majemuk). Kesalahan sintaksis biasanya ditemukan pada penggunaan frasa, klausa dan kalimat. Kesalahan leksikon adalah kesalahan yang berhubungan dengan pemilihan diksi (kosakata). Kesalahan ini biasanya 


\section{Oumanitatis}

Journal on Language and Literature Vol. 6 No. 2 June 2020

ditemukan dalam bentuk (1) ketidakcermatan pemilihan makna kata, (2) ketidakcermatan pemilihan bentuk kata, (3) ketidakcermatan pemilihan ragam bahasa, dan (4) ketidakcermatan pemilihan kata tugas.

\section{METODE PENELITIAN}

Penelitian ini menggunakan metode deskriptif kualitatif. Penelitian ini berusaha memahami dan menjelaskan fenomena kesalahan pemakaian bahasa Indonesia media luar ruang di Kota Tangerang Selatan. Penelitian ini menghasilkan data deskriptif berupa kalimat pada media luar ruang di Kota Tangerang Selatan. Sumber data dalam penelitian ini diperoleh dari sumber tulis. Sumber data tulis diperoleh dari papan iklan (billboard), Baliho, Spanduk, Umbul-Umbul dan Neon Box.

Pengumpulan data dikumpulkan dengan menggunakan teknik foto (potret). Maksudnya adalah peneliti memperhatikan dengan seksama semua pemakaian bahasa Indonesia media luar ruang di Kota Tangerang Selatan. Apabila ada terdapat kesalahan pemakaian bahasa Indonesia yang tidak sesuai dengan Pedoman Umum Ejaan Bahasa Indonesia maka peneliti akan memotret objek tersebut.

Tahapan analisis data dalam penelitian ini adalah mengelompokkan kesalahan pemakaian bahasa Indonesia berdasarkan pemakaian huruf, pemakaian kata, pemakaian tanda baca dan pemakaian unsur serapan dengan mengikuti Pedoman Umum Ejaan Bahasa Indonesia. Selanjutnya, data dianalisis dengan menggunakan teknik ganti. Teknik ganti diterapkan dengan menggantikan bentuk pemakaian bahasa Indonesia yang salah dengan bentuk pemakaian bahasa Indonesia yang sesuai dengan Pedoman Umum Ejaan Bahasa Indonesia.

Penyajian hasil penelitian dilakukan secara informal dan formal. Penyajian hasil analisis data secara informal dengan menggunakan kata-kata yang biasa dan apabila dibaca dapat langsung dipahami. Penyajian analisis data secara formal dengan menggunakan tanda, lambang-lambang dan istilah yang lazim digunakan dalam ilmu linguistik (Sudaryanto, 1993:145). 


\section{OHmanitatis}

Journal on Language and Literature Vol. 6 No. 2 June 2020

\section{TEMUAN PENELITIAN DAN PEMBAHASAN}

\subsection{Kesalahan Fonologi}

\subsubsection{Kesalahan Penulisan Kata Dasar}

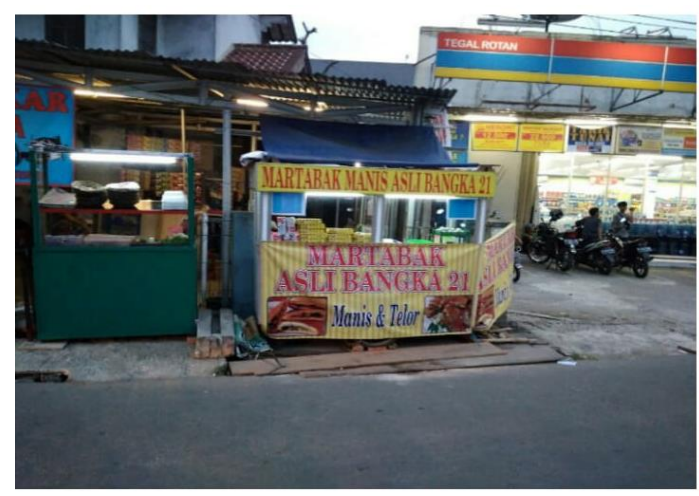

Data 1: Telor

Pada data 1, terdapat kesalahan penulisan kata dasar telor. Dalam Kamus Besar Bahasa Indonesia (2008) telor merupakan bentuk tidak baku dari kata telur. Seharusnya kata tersebut ditulis dengan kata telur bukan telor.

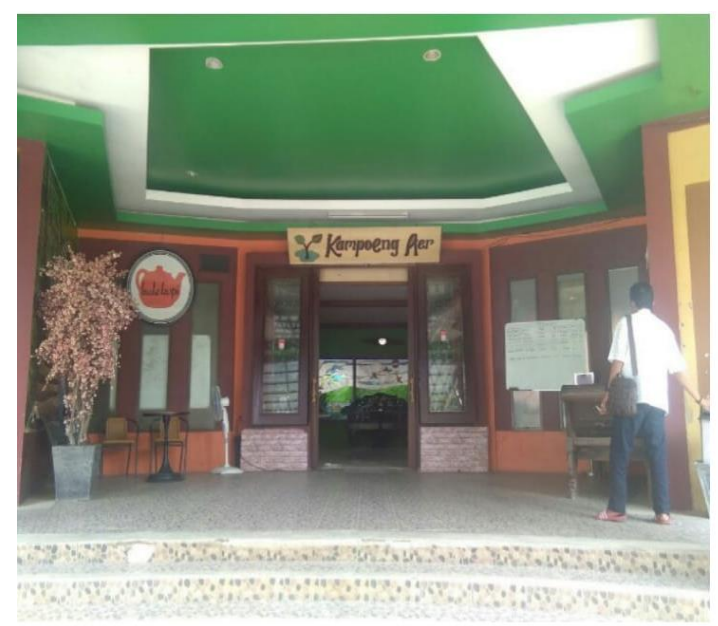

\section{Data 2: Kampoeng Aer}

Data 2 mengandung kesalahan bahasa karena tidak sesuai dengan Pedoman Umum Ejaan Bahasa Indonesia. frasa kampoeng aer tidak sesuai dengan kaidah bahasa Indonesia yang sekarang. Kata kampoeng mengikuti ejaan lama bahasa Indonesia, yaitu fonem [u] ditulis [oe]. Sedangkan pada kata aer mengandung 


\section{OUmanitatis}

Journal on Language and Literature Vol. 6 No. 2 June 2020

kesalahan karena menggunakan fonem [e], seharusnya ditulis menggunakan fonem [i]. Sehingga kedua kata tersebut, kampoeng dan air ditulis kampung air.

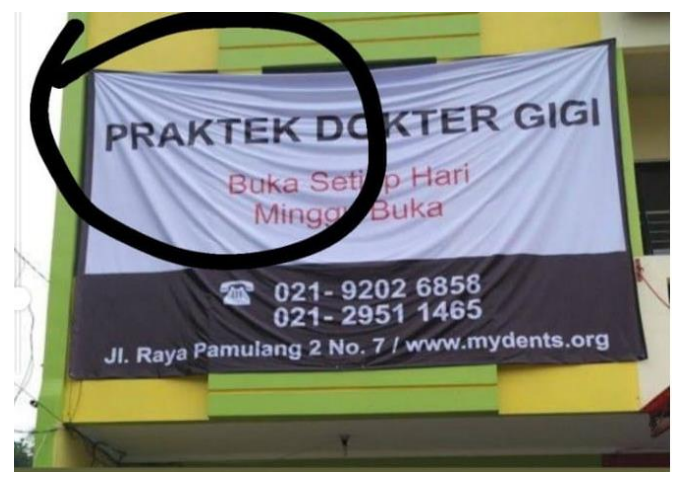

Data 3. Praktek

Pada data 3, terdapat kesalahan penulisan kata dasar praktek. Dalam Kamus Besar Bahasa Indonesia (2008) praktek merupakan bentuk tidak baku dari kata praktik. Seharusnya kata tersebut ditulis dengan kata praktik bukan praktek.

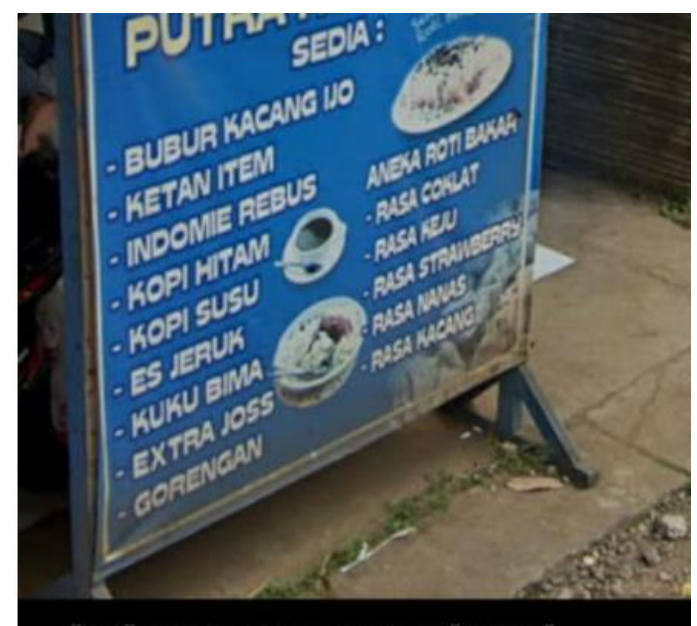

\section{Data 4. Bubur Kacang Ijo, Ketan Item, Rasa Coklat}

Data 4 mengandung kesalahan bahasa karena tidak sesuai dengan Pedoman Umum Ejaan Bahasa Indonesia. Kata ijo, item dan coklat tidak sesuai dengan kaidah bahasa Indonesia. Penulisan kata ijo dipengaruhi oleh bahasa daerah. Seharusnya kata ijo ditulis hijau. Selanjutnya, kata item juga dipengaruhi oleh bahasa daerah. Seharusnya kata item ditulis hitam. Sedangkan kata coklat merupakan bentuk tidak 


\section{OHmanitatis}

Journal on Language and Literature Vol. 6 No. 2 June 2020

baku dari kata cokelat. Jadi, ketiga kata tersebut yang benarnya adalah bubur kacang hijau, ketan hitam dan rasa Cokelat.

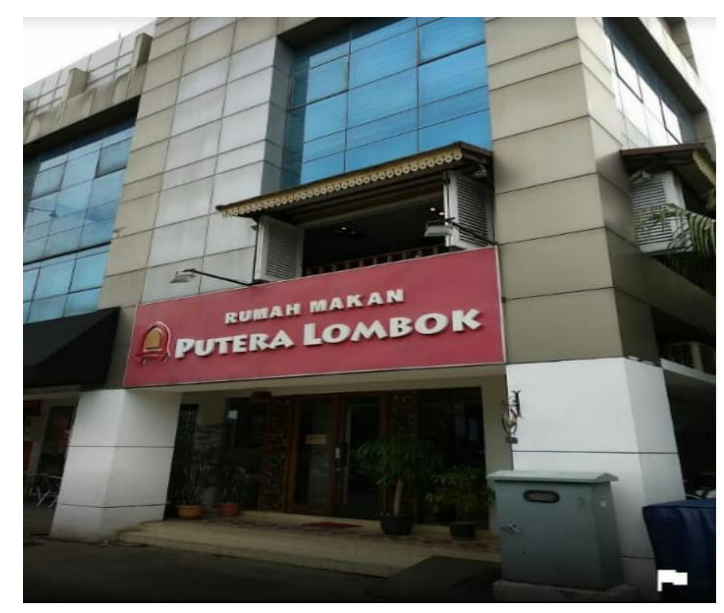

\section{Data 5. Putera Lombok}

Data 5 mengandung kesalahan bahasa karena tidak sesuai dengan Pedoman Umum Ejaan Bahasa Indonesia. Frasa putera lombok tidak sesuai dengan kaidah bahasa Indonesia yang sekarang. Kata putera merupakan bentuk tidak baku dari kata putra. Sehingga frasa putera Lombok ditulis putra Lombok.

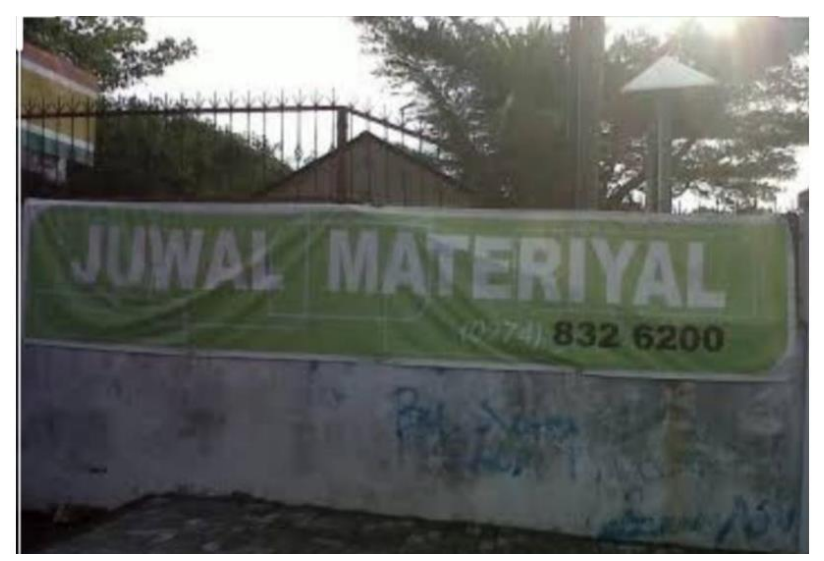

Data 5. Juwal Materiyal 


\section{OUmanitatis}

Data 5 mengandung kesalahan bahasa karena tidak sesuai dengan Pedoman Umum Ejaan Bahasa Indonesia. Frasa verba juwal materiyal tidak sesuai dengan kaidah bahasa Indonesia yang sekarang. Kesalahan penulisan pada kata juwal adalah penggunaan fonem semivokal $[w]$. Seharusnya fonem tersebut dihilangkan, sehingga penulisan yang benar adalah jual. Sedangkan, kesalahan penulisan pada kata materiyal adalah penggunaan fonem [y]. Seharusnya fonem tersebut dihilangkan, sehingga penulisan yang benar adalah material. Jadi, frasa verba juwal material harus ditulis menjadi jual material.

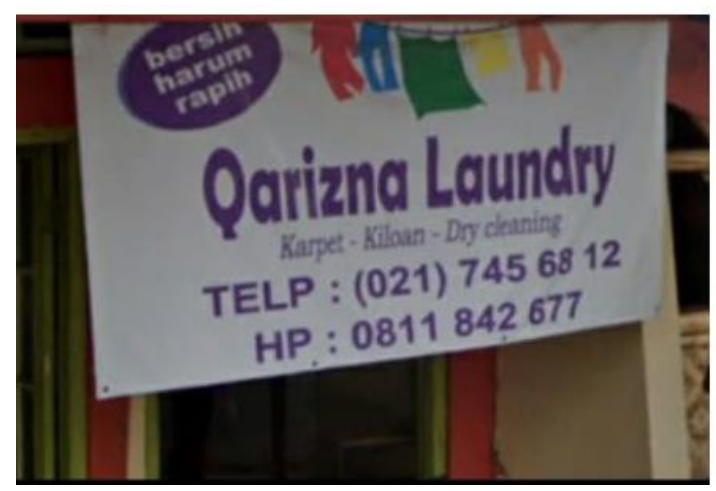

\section{Data 6. Rapih}

Pada data 6, terdapat kesalahan penulisan kata dasar rapih. Dalam Kamus Besar Bahasa Indonesia (2008) rapih merupakan bentuk tidak baku dari kata rapi. Seharusnya kata tersebut ditulis dengan kata rapi bukan rapih.

\section{b. Kesalahan Penulisan Preposisi}

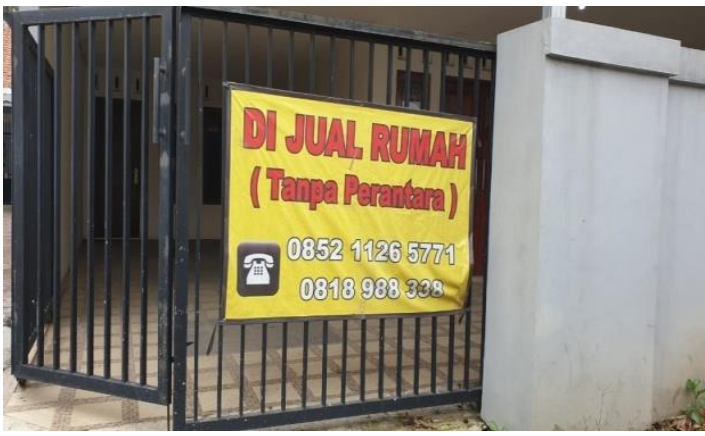

Data 7. Di Jual Rumah

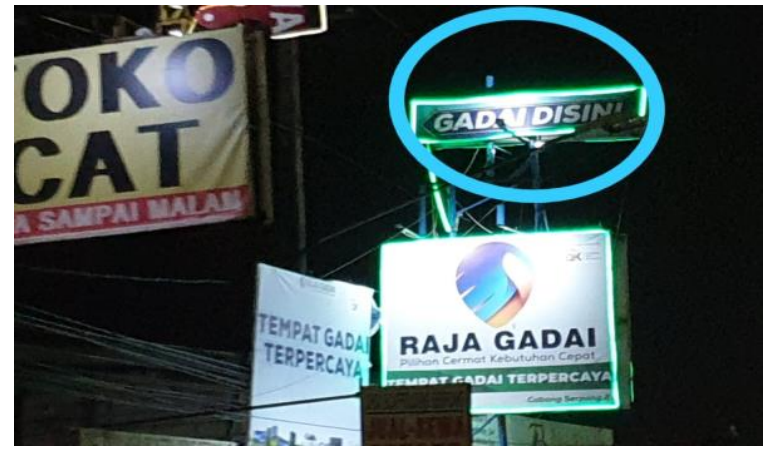

Data 8. Gadai Disini 


\section{Oumanitatis}

Journal on Language and Literature Vol. 6 No. 2 June 2020

Data 7 mengandung kesalahan bahasa karena tidak sesuai dengan Pedoman Umum Ejaan Bahasa Indonesia. Pada data 8 terdapat kesalahan pada kata di jual. Seharusnya, penulisan preposisi penanda pasif ditulis menyambung dengan kata yang dilekatinya. Sehingga, penulisan yang benar adalah dijual. Sedangkan, pada data 8 terdapat kesalahan pada kata disini. Seharusnya, penggunaan preposisi $d i$ yang menerangkan keterangan tempat seharusnya ditulis dipisah. Sehingga, penulisan yang benar adalah $d i$ sini.

\section{Kesalahan Morfologi}

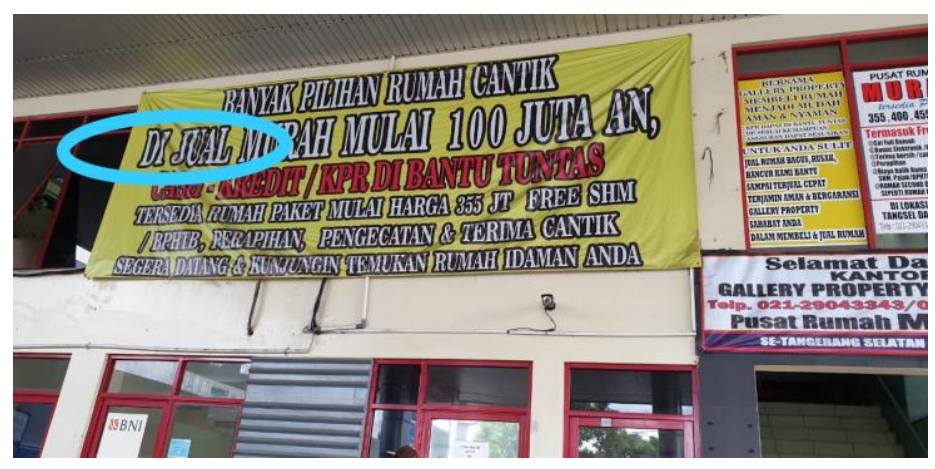

Data 9: 100 JUTA AN

Data 9 mengandung kesalahan bahasa karena tidak sesuai dengan Pedoman Umum Ejaan Bahasa Indonesia. Pada data 9 terdapat kesalahan pada kata 100 juta an. Kesalahan tersebut adalah kesalahan morfologis, yaitu penggunaan sufiks -an. Pada data 9 penggunaan sufiksnya dipisah sehingga dianggap sebagai kesalahan berbahasa. Seharusnya, penulisan sufiks -an ditulis menyambung dengan kata dasar juta. Sehingga, penulisan yang benar adalah jutaan. Kata ini bermakna berjuta-juta. 


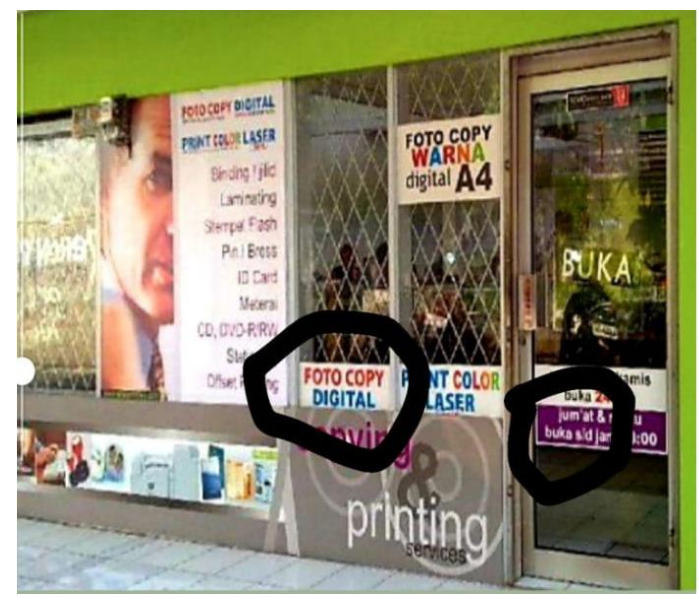

\section{Data 10: Foto Copy}

Data 10 mengandung kesalahan bahasa karena tidak sesuai dengan Pedoman Umum Ejaan Bahasa Indonesia. Pada data 9 terdapat kesalahan pada kata foto copy . Kesalahan tersebut adalah kesalahan morfologis, yaitu penulisan kata majemuk (komposisi). Jika dicari kata foto copy dalam Kamus Besar Bahasa Indonesia, maka kata tersebut tidak ditemukan. Hal ini dipengaruhi oleh terdapat campur kode dalam kata tersebut yaitu mencampurkan bahasa Indonesia foto dengan bahasa Inggris copy. Seharusnya, kata majemuk tersebut ditulis fotokopi.

\section{E. SIMPULAN}

Hasil penelitian ini menyimpulkan bahwa kesalahan berbahasa Indonesia media luar ruang di Kota Tangerang Selatan banyak ditemukan dalam bentuk kesalahan fonologi dan morfologi. Peneliti tidak menemukan kesalahan berbahasa Indonesia media luar ruang di Kota Tangerang Selatan pada tataran kesalahan leksikon. Kondisi ini menggambarkan masih banyak terdapat kesalahan berbahasa Indonesia media luar ruang di Kota Tangerang Selatan. Oleh sebab itu, perlu kebijakan pemerintah khususnya Badan Bahasa untuk melakukan penyuluhan atau penertiban penggunaan bahasa Indonesia kepada masyarakat khususnya, di Kota Tangerang Selatan. Dengan harapan, tidak ditemukan keberagaman atau kesalahan berbahasa Indonesia media luar ruang. 


\section{OUmanitatis}

Journal on Language and Literature Vol. 6 No. 2 June 2020

\section{DAFTAR PUSTAKA}

Afifah, N., \& Hasibuan, N. S. (2018). Analisis kesalahan berbahasa pada penulisan media luar ruang di wilayah Kota Medan. Linguistik: Jurnal Bahasa dan Sastra, 2(1), 14-37

Damayanti, E. (2019). Kesalahan Penggunaan Bahasa pada Iklan Komersial Media Luar Ruang di Kabupaten Kediri. Jubindo: Jurnal Ilmu Pendidikan Bahasa dan Sastra Indonesia, 4(2), 85-102.

Ghufron, S. (2015). Kesalahan berbahasa: teori dan aplikasi. Penerbit Ombak.

Hasanudin, C. (2017). Analisis Kesalahan Berbahasa Pada Penulisan Media Luar Ruang Di Kabupatenbojonegoro. Jurnal Pendidikan Bahasa dan Sastra UPI, 17(1), 120-129.

Indonesia, T. P. P. B. (2016). Pedoman umum ejaan bahasa Indonesia. Jakarta: Badan Pengembangan dan Pembinaan Bahasa.

Indonesia, T. P. K. B. B. (2008). Kamus besar bahasa Indonesia. Jakarta: Balai Pustaka.

Susanti, R. (2014). Analisis kesalahan berbahasa pada penulisan media luar ruang di kota klaten. Jurnal Sainstech, 1(1), 25-34.

Utari, T. (2018). Analisis Kesalahan Berbahasa Pada Penulisan Media Luar Ruang Di Kota Jakarta Timur. In Prosiding Kolokium Doktor dan Seminar Hasil Penelitian Hibah (Vol. 1, No. 1, pp. 497-513). 
Oeumanitatis

Journal on Language and Literature

Vol. 6 No. 2 June 2020 